\title{
Waste Cooking Oil Conversion To Biodeisel Catalized By Egg Shell Of Purebred Chiken With Ethanol As A Solvent
}

\author{
Hellna Tehubijuluw *, I Wayan Sutapa, Mealan Lethulur \\ Program Studi Kimia, FMIPA, Universitas Pattimura, Ambon \\ *E-mail: hellna_of_sukses@yahoo.com
}

\begin{abstract}
The synthesis of biodiesel from the waste cooking oil was carried out using the catalyst from egg shell of purebred chiken with ethanol as a solvent. Synthesis of biodiesel was prepared in two steps, esterification and transesterification. Esterification was conducted in mol ratio of ethanol and waste cooking oil of 9:1 with $\mathrm{H}_{2} \mathrm{SO}_{4}$ as a catalyst. Mol ratio of ethanol and used cooking oil in the transesterification of $12: 1$ with the $\mathrm{CaO}$ catalyst of shell eggs. $\mathrm{CaO}$ catalyst was yielded by calcinations egg shell of purebred chicken on $1000{ }^{\circ} \mathrm{Cfor}$ two hours. Calcination product was characterized with XRD to determine of $\mathrm{CaO}$. Result of biodiesel was characterized based on FTIR, H-NMR, dan ASTM (American Standard Testing of Materials). Theoretically,yielded of biodiesel was 58\% and experiment was $36.779 \%$.
\end{abstract}

Keywords : biodiesel, $\mathrm{CaO}$, esterification, transesterification, waste cooking oil

\begin{abstract}
ABSTRAK
Sintesisi biodiesel dari minyak goreng bekas telah dilakukan dengan menggunakan katalis dari kulit telur ayam ras dengan pelarut etanol. Proses sintesis biodiesel dilakukan melalui dua tahap yaitu esterifikasi dan transesterifikasi. Pada reaksi esterifikasi perbandingan mol etanol dan minyak goreng bekas sebesar 9:1 dengan menggunakan katalis $\mathrm{H}_{2} \mathrm{SO}_{4}$. Perbandingan mol etanol dan minyak goreng bekas pada transesterifikasi sebesar 12:1 dengan katalis $\mathrm{CaO}$ dari kulit telur ayam ras. Katalis $\mathrm{CaO}$ dihasilkan melalui proses kalsinasi kulit telur ayam ras pada suhu $1000^{\circ}$ Cselama dua jam. Hasil kalsinasi tersebut dikarakterisasi dengan XRD untuk menentukan pembentukan $\mathrm{CaO}$. Biodiesel yang dihasilkan dikarakterisasi berdasarkan FTIR, ${ }^{1}$ H-NMR, dan ASTM (American Standard Testing of Materials). Secara teoritis, biodiesel yang dihasilkan sebesar 58\% dan secara eksperimen sebesar 36,779\%.
\end{abstract}

Kata-kunci Kunci : biodiesel, $\mathrm{CaO}$, esterifikasi, minyak goreng bekas, transesterifikasi

\section{Pendahuluan}

Minyak bumi merupakan bahan bakar yang tidak dapat diperbaharui dan semakin hari ketersediaan bahan bakar minyak bumi semakin terbatas, sedangkan kebutuhan bahan bakar semakin meningkat. Dengan adanya peningkatan kebutuhan minyak, maka dampak lingkungan yang ditimbulkan juga meningkat. Usaha pengelolaan yang amat potensial adalah dengan pengembangan teknologi sumber daya energi terbarukan. Selain itu, dunia internasional saat ini juga sedang berlombalomba untuk mempergunakan bahan bakar yang ramah lingkungan dalam rangka mengimplementasikan komitmen Kyoto Protocol dan isu global mengenai CDM (Clean Development Mechanism). Salah 
satu solusi dari berbagai hal tersebut adalah biodiesel (Kuncoro, 2009).

Biodiesel merupakan salah satu energi altenatif yang dapat dipakai untuk menggantikan atau melengkapi bahan bakar yang berasal dari bahan bakar fosil seperti diesel. Secara kimiawi,biodiesel merupakan metil ester dari asam lemak rantai panjang yang berasal dari lemak yang dapat diperbaharui seperti minyak nabati dan lemak hewani.Minyak nabati merupakan bahan dasar yang menjanjikan untuk menghasilkan biodiesel karena tersedia di alam dan dapat diperbaharui sehinggga dapat diproduksi dalam skala besar dan ramah lingkungan.Namun,minyak nabati yang bersifat edible (dapat dikonsumsi) mempunyai nilai yang lebih tinggi dari biodiesel yang dihasilkan,sehingga akan terjadi persaingan fungsi sebagai pangan atau sebagai bahan dasar bahan bakar.Penggunaan bahan dasar biodiesel diarahkan ke minyak nabati nonedible (tidak dapat dikonsumsi) atau dapat juga diarahkan pada pemanfatan minyak goreng bekas mengingat minyak tersebut sudah tidak dipakai lagi dan membantu dalam penanganan limbah minyak (Zhang dkk., 2003). Jika menggunakan minyak goreng bekas maka selain memanfaatkan limbah juga dapat menaikan nilai suatu bahan yang sebelumnya tak bernilai.

Penggunaan minyak goreng bekas sebagai bahan dasar pembuatan biodiesel merupakan suatu cara alternatif yang baik untuk penanganan limbah. Namun, minyak goreng bekas tersebut mempunyai kandungan asam lemak yang lebih tinggi dibandingkan dengan minyak nabati baru.Salah satu metode untuk mengatasi hal ini adalah dengan melakukan perlakuan awal pada minyak goreng bekas untuk mengurangi kadar asam lemak bebas sebelum dilakukan transesterifikasi.

Transesterifikasi merupakan salah satu cara untuk dapat memproduksi biodiesel. Katalis basa yang sering dipakai adalah basa homogen seperti natrium hidroksida, namun jika dilihat penggunaan katalis basa homogen ini dapat menyebabkan pembentukan sabun dan juga sangat sulit dipisahkan dari bahan yang terbentuk karena bersifat homogen. Katalis homogen memiliki kelemahan yakni sangat higroskopis, bersifat korosif, sulit dipisahkan dari produk, dan katalis tidak dapat digunakan kembali(Leung dkk., 2009).Saat ini banyak industri menggunakan katalis heterogen yang mempunyai banyak keuntungan dan sifatnya ramah lingkungan, yaitu tidak bersifat korosif mudah dipisahkan dari produk,serta dapat digunakan berulangkali dalam jangka waktu yang lama (Yadav dan Thathagar, 2002). Beberapa katalis heterogen yang digunakan dalam pembuatan biodiesel sepertiCaO dan $\mathrm{MgO}$ (Liu dkk., 2008). Namun karena harganya yang mahal sehingga jika dipakai untuk menghasilkan biodiesel akan membutuhkan biaya produksi yang cukup besar. Salah satu cara untuk menghasilkan biodiesel menggunakan katalis basa heterogen namun dengan biaya produksi rendah adalah dengan menggunakan kulit telur. Diketahui bahwa bahan tersebut merupakan limbah, sehingga jika bahan tersebut digunakan maka kita dapat memanfaatkan limbah untuk menghasilkan sesuatu yang mempunyai nilai jual. Penggunaan kulit telur ini juga merupakan katalis yang murah, mudah dipisahkan dari bahan yang akan terbentuk dan tidak toksik. Selain itu pelarut yang dipakai dalam proses pembuatan biodiesel ini adalah etanol. Encinar, dkk (2002) juga telah mempelajari pengaruh jenis dan konsentrasi katalis dalam hal ini katalis basa terhadap konversi biodiesel melalui reaksi transesterifikasi dalam media etanol. Etanol lebih aman, tidak beracun dan terbuat dari hasil pertanian, etanol memiliki sifat yang sama seperti metanol yaitu berwarna bening 
seperti air, mudah menguap, dan mudah terbakar.

\section{Tujuan Penelitian}

Tujuan penelitian ini adalah sebagai berikut:

1. Melakukan uji katalis $\mathrm{CaO}$ dari kulit telur ayam ras pada reaksi transesterifikasi minyak goreng bekas.

2. Melakukan karakteristik biodiesel yang dihasilkan dari minyak goreng bekas dengan ${ }^{1} \mathrm{H}-\mathrm{NMR} \quad$ (Spektroskopi Resonansi Magnetik Inti), FTIR (Spektroskopi infra merah) dan ASTM (The American Society for Testing and Materials).

\section{Metode Penelitian}

\section{Alat}

Alat-alat gelas (pyrex), satu set alat refluks(pyrex),termometer,oven,neraca analitik, pengaduk magnet (Science Ware),ayakan ukuran 100 mesh,pemanas listrik Mammert, tanur furnace 47900 (Merck), lumpang, vacum evaporator Buchii, difraktometer sinar X- Shimadzu Goniometer XD-3A, spektrometer ${ }^{1} \mathrm{H}-\mathrm{NMR}$ JNM PMX 50 NMR, alat uji ASTM,spektrometer IR Shimadzu (FTIR8201 PC).

\section{Bahan}

Minyak goreng bekas, kulit telur ayam ras, etanol (p.a), $\mathrm{H}_{2} \mathrm{SO}_{4}$ (p.a), indikator fenolftalein, natrium sulfat anhidrous, $\mathrm{KOH}$, akuades, kertas saring (Whatman 40).

\section{Prosedur Kerja}

\section{Preparasi katalis}

Kulit telur ayam ras dicuci dengan air hingga bersih. Selanjutnya bahan dasar katalis ini dikeringkan di dalam oven pada suhu $100^{\circ} \mathrm{C}$ selama 24 jam. Bahan dasar kataliskemudian digerus dengan menggunakan lumpang hingga halus dan diayakdengan ayakan 100 mesh.

\section{Sintesis katalis $\mathrm{CaO}$ dari kulit telur}

Padatan kulit telur yang telah diayak kemudian ditimbang sebanyak 50 g. Proses sintesis $\mathrm{CaO}$ dari kulit telur dilakukan dengan memasukkan padatan yang telah ditimbang ke dalam alat kalsinasi. Proses kalsinasi padatan pada suhu $1000^{\circ} \mathrm{C}$ selama 2 jam. Setelah itu $\mathrm{CaO}$ hasil kalsinasi dikarakterisasi dengan menggunakan X-Ray Diffractometer (XRD).

\section{Preparasi minyak gorengbekas}

Minyak goreng bekas dipanaskan pada suhu $120{ }^{\circ} \mathrm{C}$ sebanyak $1 \mathrm{~L}$ untuk menguapkan air. Setelah dipanaskan minyak disaring dengan kertas saring untuk memisahkan pengotor padat yang berukuran besar. Minyak yang telah disaring tersebut selanjutnya dianalisis dengan spektroskopi infra-merah (FTIR) dan ${ }^{1} \mathrm{H}-\mathrm{NMR}$.

\section{Analisis asam lemak bebas}

Sampel sebanyak $10 \mathrm{~g}$ dimasukkan dalam labu erlenmeyer $250 \mathrm{~mL}$ dan ditambahkan $50 \mathrm{~mL}$ etanol 96\%. Setelah tercampur ditambahkan 3 tetes indikator fenolftalein.Setelah itu dilakukan titrasi dengan $\mathrm{KOH} 0,1 \mathrm{~N}$ sampai tepat warna merah jambu.Kemudian dihitung kadar asam lemak bebasnya.

\section{Pembuatan biodiesel}

\section{Proses esterifikasi}

Minyak goreng bekas yang telah dipanaskan danbersih sebanyak $450 \mathrm{~g}$ dimasukkan ke dalam labu leher tiga. Perbandingan mol minyak terhadap etanol adalah $1: 9$, dengan asumsi berat molekul minyak bekas adalah $860 \mathrm{~g} / \mathrm{mol}$. Kemudian ditambahkan $\mathrm{H}_{2} \mathrm{SO}_{4} \quad 1,25 \%$ dari jumlah total minyak dan etanol kemudian direfluks pada temperatur $70-75^{\circ} \mathrm{C}$ selama 2 jam. Akan dihasilkan 2 lapisan yaitu campuran etanol dan etil ester pada bagian atas dan trigliserida pada bagian bawah. Selanjutnya 
kedua lapisan tersebut dipisahkan dengan menggunakan corong pisah.

\section{Proses transesterifikasi}

Trigliserida yang telah dipisahkan pada proses esterifikasi selanjutnya ditransesterifikasi dengan etanol (dengan perbandingan mol 1 : 12) dan ditambahkan dengan katalis $\mathrm{CaO}$ dari kulit telur denganberat $11 \%$ dari total minyak dan etanol. Kemudian campuran direfluks kembali pada temperatur $70-75^{\circ} \mathrm{C}$ selama 7 jam. Campuran hasil reaksi didinginkan dan kemudian dipisahkan dari katalis $\mathrm{CaO}$. Kemudian campuran etil ester dan gliserol dipisahkan menggunakan corong pisah. Selanjutnya etil ester hasil esterifikasi dan transesterifikasi dievaporasi untuk menghilangkan etanol. Setelah itu dilakukan pencucian dengan akuades untuk menghilangkan sisa-sisa gliserol. Langkah terakhir adalah dengan penambahan $\mathrm{Na}_{2} \mathrm{SO}_{4}$ anhidrous sebanyak 1,5 g untuk mengikat sisa-sisa air, kemudian disaring dengan kertas saring Whatman 40.Etil ester yang diperoleh dianalisis komposisi kimianya dengan FTIR dan ${ }^{1} \mathrm{H}-\mathrm{NMR}$, selanjutnya diuji karakter fisiknya dengan metode standar ASTM (kerapatan, viskositas, titik nyala, titik tuang, dan sisa karbon Condrason).

\section{Pembahasan}

\section{Sintesis dan Karakterisasi $\mathrm{CaO}$ dari Kulit Telur Ayam Ras}

\section{Sintesis $\mathrm{CaO}$ dari kulit telur ayam ras}

Sintesis katalis $\mathrm{CaO}$ kulit telur ayam ras diawali dengan proses pembersihan dan pengeringan kulit telur dalam oven pada suhu $100 \quad{ }^{\circ} \mathrm{C}$ selama 24 jam untuk menghilangkan kotoran dan air, digerus dengan lumpang hingga halus, dan diayak hingga ukuran 100 mesh. Proses pengayakan ini bertujuan untuk memperkecil ukuran butiran sekaligus memperbesar permukaan padatan. Padatan kulit telur ayam ras tersebut dikalsinasi dengan suhu $1000{ }^{\circ} \mathrm{C}$ selama 2 jam untuk mensintesis $\mathrm{CaO}$. Proses pemanasan dengan suhu tinggi dapat menghilangkan $\mathrm{CO}_{2}$ dari $\mathrm{CaCO}_{3}$ sehingga dapat diperoleh $\mathrm{CaO}$. Konversi $\mathrm{CaO}$ yang diperoleh dari kalsinasi $50 \mathrm{~g}$ kulit telur adalah sebesar 54,942\%

\section{Karakterisasi $\mathrm{CaO}$ dari kulit telur ayam ras dengan difraktometer sinar-X (XRD)}

Uji pada katalis bertujuan untuk mengetahui apakah telah terbentuk $\mathrm{CaO}$ dari kulit telur ayam ras. Hasil XRD pada kulit telur ayam ras sebelum dikalsinasi diperlihatkan oleh difraktogram (Gambar 1)yang menghasilkan puncak-puncak $2 \theta$ dengan karakteristik $\mathrm{CaCO}_{3}$ melalui munculnya puncak-puncak pada $2 \theta=$ 23,$3209 ; \quad 26,7654 ; \quad 29,6767 ; \quad 35,7421$; 36,$2533 ; \quad 39,0923 ; \quad 39,7038 ; \quad 42,9632$; 43,$4632 ; \quad 43.8545 ; \quad 47,4152 ; \quad 47,8133$; 48,$8031 ; 57,7074 ; 60,9839 ; 64,9793$. Dari 16 puncak tersebut terdapat 3 refleksi yang paling dominan yaitu pada $2 \theta=29,6767$ dengan intensitas $3465,2 \theta=26,7654$ dengan intensitas 850 , dan pada $2 \theta=$ 47,8133 dengan intensitas 507

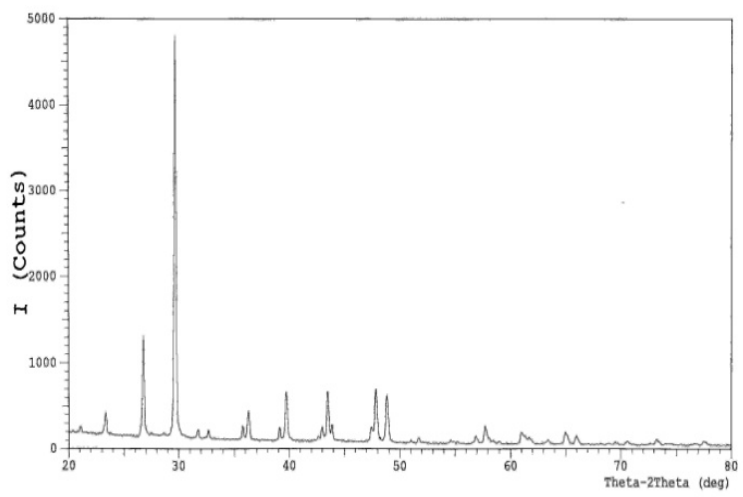

Gambar 1.Difraktogram kulit telur ayam ras 
Difraktogram hasil XRD pada kulit telur ayam ras yang telah dikalsinasi pada suhu $1000{ }^{\circ} \mathrm{C}$ (Gambar 2) menghasilkan perubahan pola difraksi yang ditunjukkan oleh puncak-puncak pada $2 \theta=29,1246$; 32,$3139 ; \quad 33,7399 ; \quad 33,9632 ; \quad 37,4728$; 48,$4312 ; \quad 48,7092 ; 53,9871 ; \quad 57,4708$; 60,$2812 ; 64,2897 ; 67,5088 ; 79,8062$. Dari 13 puncak tersebut terdapat 3 puncak yang refleksi paling dominan yaitu pada $2 \theta=$ 37,4728 dengan intensitas 2897, $2 \theta=$ 53,9871 dengan intensitas 1627 , dan pada $2 \theta=32,3139$ dengan intensitas 1061

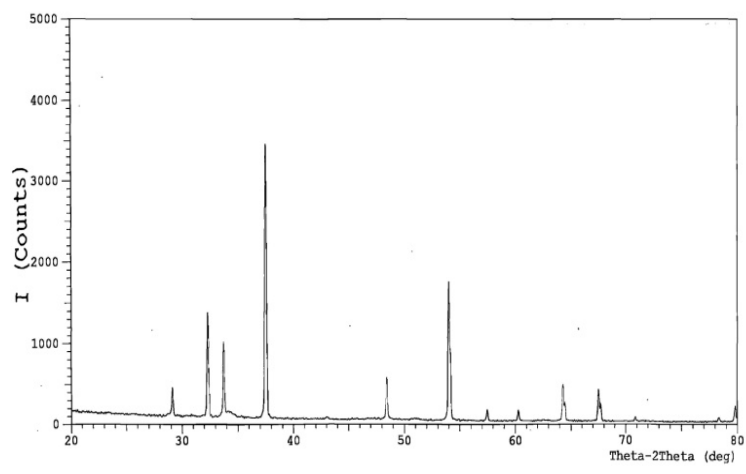

Gambar 2. Difraktogram $\mathrm{CaO}$ hasil kalsinasi

Hasil XRD kulit telur ayam ras yang telah dikalsinasi menunjukkan pola difraksi pada $\mathrm{CaO}$ murni (Gambar 3), yang ditunjukkan pada puncak-puncak yang refleksi paling domina pada $2 \theta=37,4728$; 53,9871; 32,3139. Perubahan pola difraksi ini terjadi karena adanya perlakuan panas pada kulit telur ayam ras sehingga terjadi penghilangan $\mathrm{CO}_{2}$ dari senyawa awal yang dominan pada kulit telur ayam ras yakni $\mathrm{CaCO}_{3}$ menghasilkan $\mathrm{CaO}$. Pola difraksi pada sampel dengan pemanasan pada suhu $<700^{\circ} \mathrm{C}$ masih terlihat karakteristik dari $\mathrm{CaCO}_{3}$ (dapat dilihat pada Gambar 4). Namun pada suhu $>700{ }^{\circ} \mathrm{C}$ mulai terlihat karakteristik dari $\mathrm{CaO}$. Pada suhu $1000{ }^{\circ} \mathrm{C}$ pola difraksi dari sampel $\mathrm{CaO}$ dari kulit telur ayam ras setelah dikalsinasi hasilnya hampir sama dengan pola difraksi yang ditunjukkan pada $\mathrm{CaO}$ murni. Difraktogram pada padatan kulit telur setelah dikalsinasi terdapat puncak difraksi yang sempit dan tajam atau kuat yang menunjukkan bahwa katalis yang diperoleh memiliki tingkat kristalinitas yang tinggi.

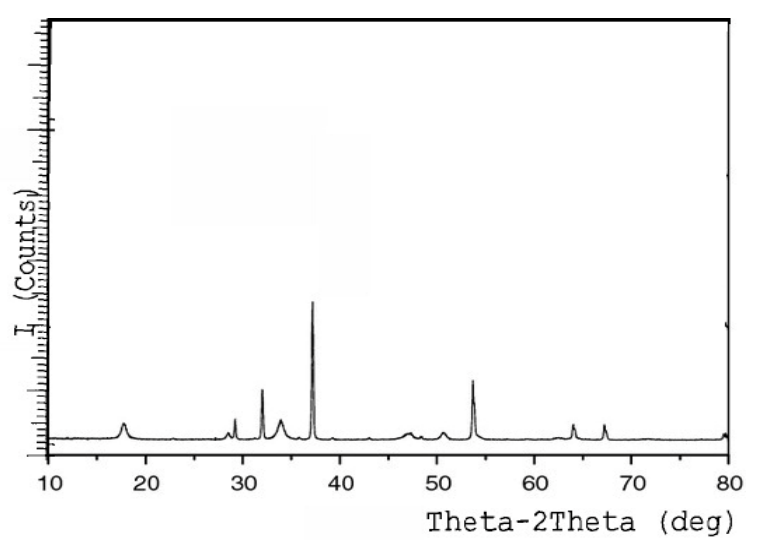

Gambar 3. Difraktogram $\mathrm{CaO}$ murni

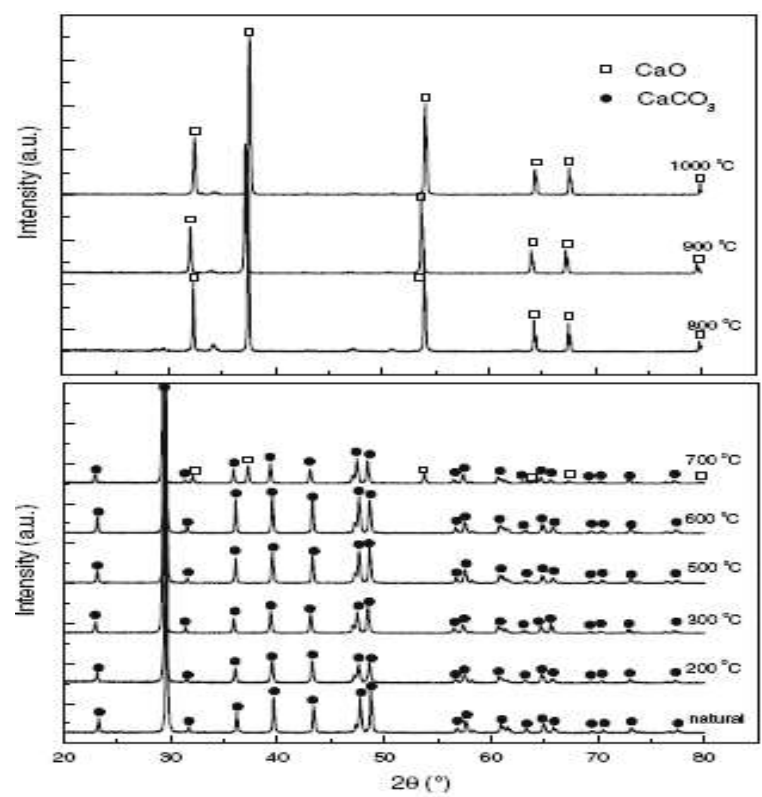

Gambar 4. Pola-pola difraktogram untuk kulit telur segar dan material yang diperoleh dari kalsinasi kulit telur segar pada rentang suhu $200^{\circ} \mathrm{C}-1000^{\circ} \mathrm{C}$ ( Wei dkk., 2009)

EKSAKTA Vol. 14 No. 1 Februari 2014, 52-64 


\section{Sintesis Biodiesel}

\section{Proses esterifikasi}

Bahan baku yang digunakan dalam penelitian ini adalah minyak goreng bekas. Preparasi bahan baku sangat diperlukan mengingat bahan baku yang dipakai dalam hal ini minyak goreng bekas merupakan limbah, sehingga pengotor maupun kandungan air yang terdapat dalam minyak goreng bekas tersebut perlu dihilangkan. Salah satu cara yang dapat dilakukan adalah dengan pemanasan dan penyaringan.

Dalam proses sintesis biodiesel dari minyak goreng bekas ada 2 proses yang harus dilakukan yaitu proses esterifikasi dan proses transesterifikasi. Pada proses ini dilakukan reaksi esterifikasi terlebih dahulu agar mengurangi kandungan asam lemak bebas pada minyak minyak goreng bekas. Walaupun minyak goreng bekas yang dipakai memiliki jumlah asam lemak bebas yang tidak terlalu besar yaitu 2,3\% namun keberadaannya tidak dapat diabaikan karena dapat mengurangi jumlah etil ester yang didapat sehingga proses esterifikasi ini perlu dilakukan. Hal ini sesuai dengan pernyataan Mastutik(2006) yang menyatakan bahwa minyak atau lemak yang memiliki kandungan asam lemak bebas tinggi seperti minyak jelantah $(2-7)$ dan lemak hewan $(5-30 \%)$ perlu dilakukan dua langkah dengan katalis asam dan katalis basa untuk mengatasi asam lemak bebas yang tinggi dalam memproduksi biodiesel.

Proses esterifikasiini dilakukan dengan mereaksikan etanol dengan sampel (minyak goreng bekas) dengan perbandingan 1 : 9 dengan asumsi bahwa berat molekul minyak goreng bekas adalah $860 \mathrm{~g} / \mathrm{mol}$ dan dengan bantuan asam sulfat $1 \mathrm{M}$ sebagai katalis. Perefluksan pada proses esterifikasi dilakukan pada suhu 70 $75^{\circ} \mathrm{C}$ yaitu pada suhu mendekati suhu titik didih etanol selama 7 jam dan akan terbentuk 2 lapisan yaitu campuran etanol dan etil ester pada lapisan bagian atas dan trigliserida pada lapisan bagian bawah (trigliserida) yang selanjutnya akan ditransesterifikasi.

\section{Proses transesterifikasi}

Proses tranesterifikasi dilakukan dengan menggunakan katalis basa heterogen $\mathrm{CaO}$ yang diperoleh dari kulit telur ayam ras yang telah dikalsinasi.Perbandingan etanol terhadap minyak pada proses transesterifikasi lebih besar dibandingkan dengan proses esterifikasi yaitu 1 : 12 karena jumlah trigliserida akan diubah menjadi etil ester lebih besar dari asam lemak bebas yang diubah menjadi etil ester pada proses esterifikasi. Proses transesterifikasi ini dilakukan dengan cara mereaksikan etanol dengan trigliserida dengan bantuan katalis $\mathrm{CaO} 11 \%$ dari kulit telur ayam ras. Mekanisme transesterifikasi seperti pada Gambar 5.

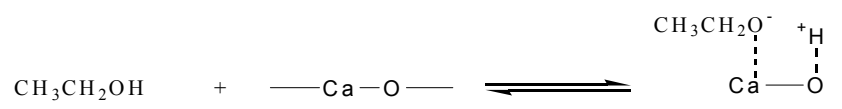



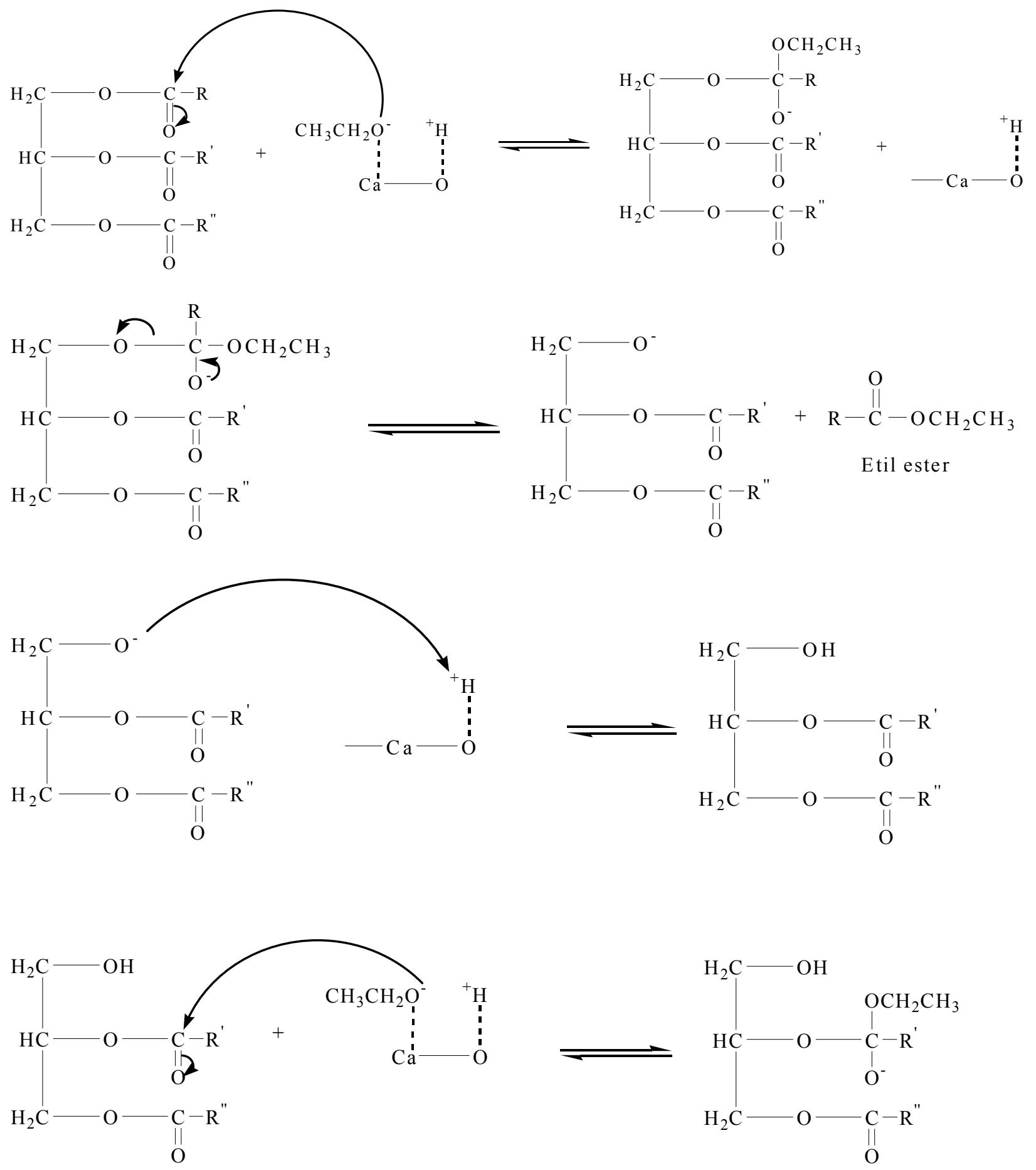

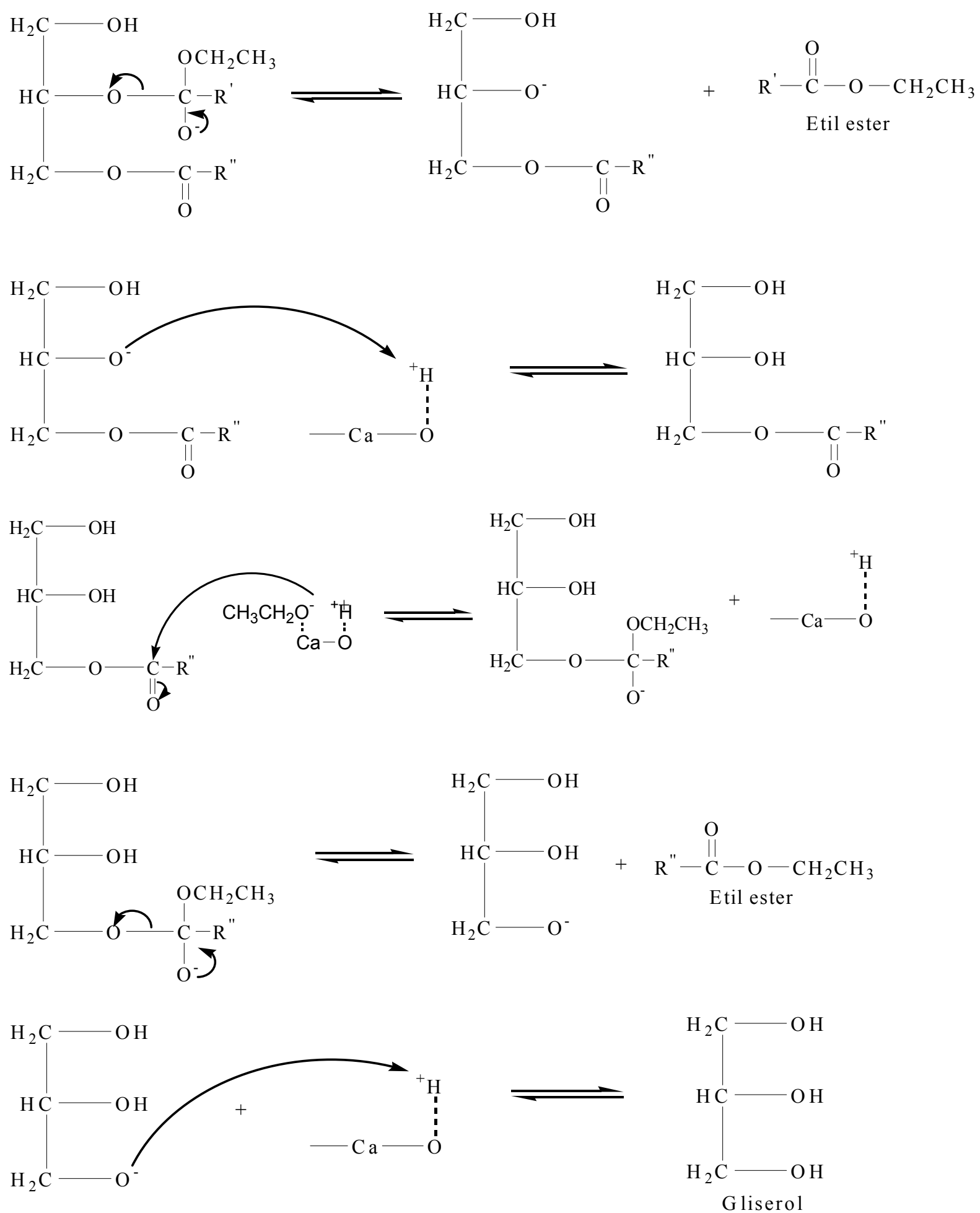

Gambar 5. Mekanisme reaksi transesterifikasi dengan menggunakan katalis basa $\mathrm{CaO}$ 
Etil ester hasil transesterifikasi selanjutnyadievaporasi pada suhu $78,9{ }^{\circ} \mathrm{C}$ sesuai dengan titik didih etanol untuk menghilangkan sisa etanol. Kemudian dilakukan pencucian dengan akuades untuk menghilangkan sisa-sisa gliserol.

Pada etil ester hasil pemisahan dari air dilakukan penambahan $\mathrm{Na}_{2} \mathrm{SO}_{4}$ anhidrat yang berfungsi untuk mengikat sisa-sisa air yang masih terdapat dalam etil ester. Kemudian disaring dengan kertas saring whatman 40 dan diperoleh etil ester (biodiesel),selanjutnya akan dikarakterisasi sifat kimia dan fisiknya.Konversi etil ester dari minyak goreng bekas melalui proses esterifikasi dan transesterifikasi secara eksperimen adalah sebesar 36,779\%.

\section{Karakterisasi Biodiesel}

\section{Analisis biodiesel dengan spektroskopi infra merah (FTIR)}

Pengujian FT-IR dilakukan untuk membuktikan adanya ester pada produk transesterifikasi. Adanya ester, dapat dilihat dari serapan khas pada gugus $\mathrm{C}=\mathrm{O}$ dan $\mathrm{C}$ $\mathrm{O}$.

Berdasarkan Tabel 1 dan Tabel 2 menunjukkan perubahan serapan dari gugus karbonil $(\mathrm{C}=\mathrm{O})$ dan gugus esternya $(\mathrm{C}-\mathrm{O})$. Gugus karbonil $(\mathrm{C}=\mathrm{O})$ pada minyak goreng bekas memiliki serapan kuat pada 1743,65 $\mathrm{cm}^{-1}$ berubah menjadi $1740,79 \mathrm{~cm}^{-1}$ pada biodiesel sedangkan untuk gugus $\mathrm{C}-\mathrm{O}$, terjadi perubahan dari $1165,00 \mathrm{~cm}^{-1}$ menjadi $1180,46 \mathrm{~cm}^{-1}$. Serapan pada $3000,32 \mathrm{~cm}^{-1}$ merupakan serapan khas untuk $\mathrm{C}-\mathrm{H}$ pada gugus alkena $(-\mathrm{CH}=\mathrm{CH}-)$ yang menandakan adanya asam lemak takjenuh, hal ini diperkuat dengan adanya serapan pada $758,04 \mathrm{~cm}^{-1}$. Serapan kuat pada pada daerah $2854,70-2955,00 \mathrm{~cm}^{-1}$ merupakan serapan untuk C-H alifatik (streching), ini diperkuat dengan serapan pada $1445,67 \mathrm{~cm}^{-1}$ $1465,93 \mathrm{~cm}^{-1}$ yang merupakan serapan untuk $\mathrm{CH}_{2}$ dan $1369,48 \mathrm{~cm}^{-1}$ untuk $\mathrm{CH}_{3}$.
Serapan pada $3467,11 \mathrm{~cm}^{-1}$ merupakan serapan khas untuk gugus $\mathrm{OH}$ dari gliserol.

Tabel 1. Data spektra IR minyak goreng bekas

\begin{tabular}{ll}
\hline $\begin{array}{c}\text { Bilangan Gelombang } \\
\left(\mathbf{c m}^{-1}\right)\end{array}$ & \multicolumn{1}{c}{ Keterangan } \\
\hline $\mathbf{1 7 4 3 , 6 5}$ & $\mathrm{C}=\mathrm{O}$ \\
$\mathbf{1 1 6 5 , 0 0}$ & $\mathrm{C}-\mathrm{O}$ \\
$\mathbf{2 8 5 4 , 6 5 - 2 9 2 4 , 0 9}$ & $\mathrm{C}-\mathrm{H}$ (alifatik) \\
$\mathbf{3 4 7 1 , 8 7}$ & OH \\
& \\
\hline
\end{tabular}

Tabel 2. Data spektra IR biodiesel

\begin{tabular}{ll}
\hline $\begin{array}{c}\text { Bilangan Gelombang } \\
\left(\mathbf{c m}^{-1}\right)\end{array}$ & Keterangan \\
\hline 1740,79 & $\mathrm{C}=\mathrm{O}$ \\
1180,46 & $\mathrm{C}-\mathrm{O}$ \\
$2854,70-2955,09$ & $\mathrm{C}-\mathrm{H}$ (alifatik) \\
3467,11 & $\mathrm{OH}$ \\
3000,32 & $-\mathrm{CH}=\mathrm{CH}-$ \\
\hline
\end{tabular}

\section{Analisis biodiesel dengan spektroskopi} ${ }^{1}$ H-NMR

Biodiesel yang telah didapat melalui reaksi esterifikasi dan transesterifikasi kemudian dianalisis dengan spektroskopi ${ }^{1} \mathrm{H}-\mathrm{NMR}$ untuk mengetahui persentase konversi biodiesel dari minyak goreng tersebut.

Pada spektra ${ }^{1} \mathrm{H}-\mathrm{NMR}$ minyak goreng bekas(Gambar6) dapat dilihat adanya proton dari gugus gliserida yang ditunjukkan pada daerah $4-4,3$ ppm dan 5 - 6 ppm. Gliserida ini akan diubah pada proses transesterifikasi. 


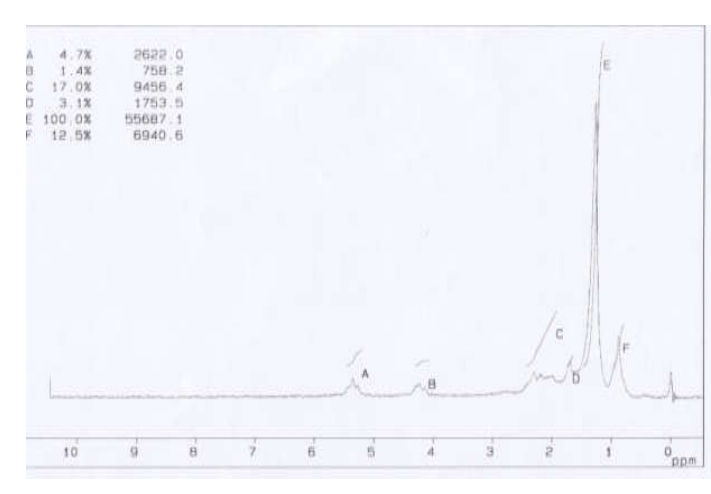

Gambar 6. Spektra ${ }^{1} \mathrm{H}-\mathrm{NMR}$ minyak goreng bekas

Pada hasil spektra ${ }^{1} \mathrm{H}-\mathrm{NMR}$ biodiesel (Gambar 7) terlihat adanya proton dari etil ester pada daerah 4,2 ppm dan terlihat proton dari gugus gliserida pada pada daerah 5-6 ppm.Pada daerah 1-2 ppm muncul puncak yang lebar dan tinggi, puncak ini terjadi karena proton-proton pada $\mathrm{CH}_{2}$ asam lemak berada terlalu dekat sehingga geseran kimia juga menjadi terlalu dekat akibatnya puncak-puncak akan bergabung menjadi suatu singlet dimana puncak-puncak tengah suatu multiplet makin tinggi sementara puncak-puncak pinggir akan mengecil. Hal ini disebut juga gejala pemiringan atau learning (Fessenden dan Fessenden, 1991).

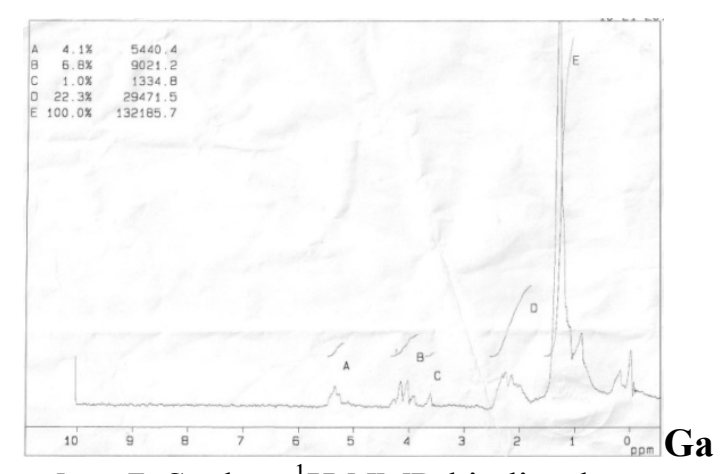

mbar 7. Spektra ${ }^{1} \mathrm{H}-\mathrm{NMR}$ biodiesel
Konversi etil ester (biodiesel) yang terbentuk dapat diketahui dengan menggunakan Persamaan 1 secara teoritik.

$\mathrm{C}_{\mathrm{ME}}=100 \times \frac{\mathbf{s} \times \mathrm{I}_{\mathrm{ME}}}{5 \times I_{\mathrm{ME}}+9 \times \mathrm{I}_{\mathrm{TAG}}} \ldots$

dengan $\mathrm{C}_{\mathrm{ME}}$ adalah konversi metil ester $(\%), \mathrm{I}_{\mathrm{ME}}$ adalah nilai integrasi puncak metil ester (\%), $\mathrm{I}_{\mathrm{TAG}}$ adalah nilai integrasi puncak triasilgliserol (\%).Faktor 5 dan 9 adalah jumlah proton yang terdapat pada gliserol dalam molekul trigliserida mempunyai 5 proton dan 3 molekul metil ester yang dihasilkan dari 1 molekul trigliserida (TG) mempunyai 9 proton (Knothe, 2000).

Spektra biodiesel yang diperoleh (Gambar 7) menunjukkan spektra gliserol pada daerah 5-6 ppm. Pada Persamaan 1 diperoleh konversi etil ester (biodiesel) sebesar $58 \%$.Puncak yang digunakan untuk menentukan konversi etil ester (biodiesel) adalah puncak pada pergeseran kimia 4,2 ppm yang merupakan spektra etil ester (B), dan puncak pada pergeseran kimia 5-6 ppm yang merupakan spektra dari gugus gliserol (A).

\section{Analisis sifat fisik biodiesel dengan metode ASTM}

Analisis sifat fisik biodiesel dari minyak goreng bekas yang diperoleh melalui metode pemeriksaan ASTM (The American Society for Testing and Materials) akan dibandingkan dengan standar minyak diesel dan SNI biodiesel. 
Tabel 3. Perbandingan sifat fisik biodiesel dari minyak goreng bekas dengan minyak diesel

\begin{tabular}{llllll}
\hline No & Jenis & Metode & $\begin{array}{l}\text { Hasil } \\
\text { Pemeriksaan } \\
\text { Biodiesel }\end{array}$ & $\begin{array}{l}\text { SNI } \\
\text { Biodiesel*) }\end{array}$ & $\begin{array}{l}\text { Batasan } \\
\text { Solar**) }\end{array}$ \\
& & &
\end{tabular}

\begin{tabular}{llllll}
\hline $\mathbf{1}$ & $\begin{array}{l}\text { Kerapatan Spesifik } \\
\text { 60/60 F, kg/m3 }\end{array}$ & ASTM D 1298 & 0,8780 & $0,850-$ & $0,815-$ \\
$\mathbf{2}$ & $\begin{array}{l}\text { Viskositas } \\
\text { Kinematis 40 C, } \\
\text { mm2/s }\end{array}$ & ASTM D 445 & 6,690 & 0,870 \\
$\mathbf{3}$ & $\begin{array}{l}\text { Titik Nyala - } \\
\text { PM.cc, C }\end{array}$ & ASTM D 93 & 156,5 & min. 100 & min. 60 \\
$\mathbf{4}$ & $\begin{array}{l}\text { Titik Tuang, C } \\
\mathbf{5}\end{array}$ & ASTM D 97 & 6 & maks. 18 & maks.18 \\
Sisa Karbon & ASTM D 189 & 0,4229 & maks.0,30 & maks.0,30 \\
\hline
\end{tabular}

*) SNI-04-7182-2006 diterbitkan oleh Badan Standarisasi Nasional (BSN) tanggal 22 Februari 2006

**)Spesifikasi solar sesuai SK Dirjen Migas No. 3675K/24/DJM/2006

Tabel 3 menunjukkan bahwa kerapatan spesifik biodiesel dari minyak goreng bekas yaitu sebesar $0,8780 \mathrm{~kg} / \mathrm{m}^{3}$ telah memenuhi spesifikasi SNI biodiesel. Nilai viskositas kinematik yang dihasilkan oleh biodiesel yaitu sebesar $6,616 \mathrm{~mm}^{2} / \mathrm{s}$ juga melebihi spesifikasi SNI biodiesel hal ini disebabkan trigliserida belum terurai sempurna.

Pada tingkat konversi yang rendah dimungkinkan biodiesel masih mengandung molekul gliserida baik berupa tri-, di- dan mono-gliserida, di mana gugus hidroksida pada molekul digliserida dan monogliserida dapat menyebabkan terbentuknya ikatan hidrogen yang sangat kuat sehingga menambah kerapatan antar molekul gliserida. Akibat pembentukan ikatan hidrogen antar molekul tersebut juga akan meningkatkan viskositas kinematik dari senyawa (Kuncoro, 2009).

Titik nyala yang tinggi akan memudahkan dalam proses penanganan, penyimpanan, dan pengangkutan karena dapat mengurangi resiko penyalaan. Juga aman pada daerah yang beriklim tropis yang panas. Apabila titik nyala bahan bakar rendah maka bahan bakar tersebut mudah terbakardalam penyimpanannya. Hasil uji titik nyalabiodiesel dari minyak goreng bekas yaitu sebesar $156,5{ }^{\circ} \mathrm{C}$ telah memenuhi spesifikasi SNI biodiesel dan nilainya sangat tinggi dibandingkan dengan batasan minyak solar. Nilai titik nyala ini membuat biodiesel dari minyak goreng bekas aman disimpan walaupun terjadi kenaikan suhu diatas suhu kamar.

Titik tuang biodiesel dari minyak goreng bekas yaitu sebesar $6^{\circ} \mathrm{C}$ telah memenuhi spesifikasi SNI biodiesel. Titik tuang menunjukkan suhu dimana minyak mulai membeku atau berhenti mengalir. Titik tuang yang tinggi akan membuat mesin sulit dinyalakan pada suhu yang rendah. Nilai titik tuang biodiesel dari minyak goreng bekas ini membuat

EKSAKTA Vol. 14 No. 1 Februari 2014, 52-64 
penggunaan biodiesel pada mesin diesel akan mudah menyala pada suhu rendah.

Sisa karbonCondrasonadalah nilai karbon yang tertinggal setelah penguapan dan pembakaran habis. Dapat dilihat pada Tabel 3 bahwa sisa karbon condrason biodiesel minyak goreng bekas yaitu sebesar $0,4229 \%$ wt tidak memenuhi spesifikasi SNI biodiesel. Nilai sisa karbon Condrason yang semakin tinggi menunjukkan bahwa pada proses transesterifikasi penguraian trigliserida yang terjadi belum mendekati sempurna.

Dari uraian yang telah dikemukakan tersebut dapat diketahui bahwa biodiesel yang dihasilkan dari minyak goreng bekas dengan katalis $\mathrm{CaO}$ dari kulit telur ayam ras mempunyai kelebihan dibanding diesel. Biodesel mempunyai titik nyala yang tinggi $156,5{ }^{\circ} \mathrm{C}$ sehingga memudahkan dalam proses penyimpanan karena dapat mengurangi resiko penyalaan.

\section{Kesimpulan}

Berdasarkan hasil penelitian yang dilakukan maka dapat disimpulkan sebagai berikut :

1. Pembuatan biodiesel dari minyak goreng bekas melalui proses esterifikasi dan transesterifikasi dengan menggunakan katalis kulit telur ayam ras ini menghasilkan $58 \%$.

2. Biodiesel yang dihasilkan dari minyak goreng bekas dengan menggunakan katalis dari kulit telur ayam ras memiliki kualifikasi sebagai bahan bakar diesel dan hampir mendekati karakter minyak diesel menurut ASTM.

\section{Pustaka}

Enchinar, J.M., Gonzales J.F., Rodrigues, J.J. dan Tejedor, A., 2002, Biodiesel Fuels from Vegetables Oils. Transesterification of Cynara cardulus L. Oils with ethanol, Energy and Fuels, 16.
Fessenden dan Fessenden, 1991, Kimia Organik, Jilid 2 Edisi ketiga, Erlangga, Jakarta.

Knothe, G. 2000. Monitoring a Progressing Transesterification Reaction by Fiber- Optic Near Infrared Spectroscopy with correlation to $\mathrm{H}$ Nuclear Magnetic Resonance Spectroscopy, Jmp. AM. Oil. Chem. Soc.77, J 9483, 489-493.

Kuncoro, H. 2009. Konversi Lemak Ayam menjadi Biodiesel dengan Katalis Zeolit Alam Klaten Terektifasi $\mathrm{H}_{2} \mathrm{SO}_{4}$ pada Reaktor Biodiesel Sederhana. Tesis. FMIPA UGM,Yogyakarta

Leung, D. Y.C., Wu, X., dan Leung, M.K.H., 2009, a Review on Biodiesel Production using Catalyzed Transesterification, Applied Energy, 8:1083:1095.

Liu, X., He, H., Wang, Y., Zhu, S., dan Piano, X., 2008, Transesterification of Soybean Oil to Biodiesel using $\mathrm{CaO}$ as a Solid Base Catalyst, Fuel87:216221.

Mastutik, D. 2006. Transesterifikasi Minyak Jelantah Kelapa Sawit menjadi Biodiesel Menggunakan Katalis $\mathrm{NaOH}$ tanpa Proses Esterfikasi dan Katalis Asam $\left(\mathrm{H}_{2} \mathrm{SO}_{4}\right.$ dan zeolit-Y) melalui Proses Esteridikasi. Tesis. FMIPAUGM, Yogyakarta

Wei, Z., Xu, C., dan Li, B. 2009. Application of Waste Eggshell as Low-Cost Solid Catalyst for Biodiesel Production. Bioresour. Techonool.100, 28832885. 
Yadav, G. D. dan Thathagar, M. B., 2002, Esterification of Maleic Acid with Ethanol Over Cation-Exchange Resin Catalyst. React. Funct. Polym., 52, 99-110.

Zhang, Y., M.A. Dube, McLean, D.D., dan Kates, M. 2003. Biodiesel Production from Waste Cooking Oil: 1. Process Design and Technological

Assessment ; Review Paper.

Bioresource Techonology, 89, 1-16 